IJBPAS, February, 2022, 11(2): 808-817

ISSN: 2277-4998

International Journal of Biology, Pharmacy

and Allied Seiences (IJBPAS)

'A Bridge Betueen Caboratory and QRender'

Www.iibpas.com

\title{
QUANTIFICATION OF ANTI-DIABETIC COMBINATION DRUGS BY HPTLC METHOD
}

\section{MOHASEENA SHAIK*, SIVA PRASAD MORLA, P.PRACHET, P.SAI.PRIYA AND RAMA RAO NADENDLA}

Department of Pharmaceutical Analysis, Chalapathi Institute of Pharmaceutical Sciences, Lam, Guntur-522034

*Corresponding Author: Mohaseena Shaik: E Mail: mohaseena199705@gmail.com

Received 17 $7^{\text {th }}$ March 2021; Revised 18 ${ }^{\text {th }}$ April 2021; Accepted $7^{\text {th }}$ June 2021; Available online $1^{\text {st }}$ Feb. 2022

\section{https://doi.org/10.31032/IJBPAS/2022/11.2.5908}

\begin{abstract}
Pioglitazone and Glimepride are used for the treatment of type-II diabetes mellitus. Accurate, rapid, simple, precise high performance thin layer chromatographic method (HPTLC) for Pioglitazone and Glimepride has been established and validated according to ICH guideline. Separation was achieved on silica gel 60 F254 plates with Toluene: Ethyl acetate: Diethyl ether (6:3:1v/v/v) used as mobile phase. The Rf values for Pioglitazone and Glimepride were found to be 0.88 and 0.79 .Results were linear in range of $6000-12000 \mathrm{ng} / \mathrm{mL}$ for Pioglitazone and 800 $1600 \mathrm{ng} / \mathrm{mL}$ for Glimepride. The repeatability testing for sample and standard solutions were found as \%RSD NMT 2.0\% which was within the acceptable limits. Percentage recovery for Pioglitazone is 100.06\% and for Glimepride is 99.94\%. LOD for Pioglitazone and Glimepride was found to be $2.75 \mathrm{ng} / \mathrm{mL}$ and $1.10 \mathrm{ng} / \mathrm{mL}$ and LOQ for Pioglitazone and Glimepride was $8.34 \mathrm{ng} / \mathrm{mL}$ and $3.33 \mathrm{ng} / \mathrm{mL}$. The developed method was validated for linearity, precision, accuracy, robustness, limit of detection, limit of quantification according to ICH guideline.
\end{abstract}

Keywords: HPTLC, Pioglitazone, Glimepride, LOD, LOQ, PIO, GLI 


\section{INTRODUCTION}

Pioglitazone is a thiazolidinedione derivative chemically it is 5-[[4-[2-(5-ethylpyridin-2-yl) ethoxy]phenyl]methyl]-1,3-thiazolidine-2,4dione [1]. It is one of the PPAR-alpha agonist, insulin sensitizer used to reduce the insulin resistance [2]. Glimepride (GLI) is a sulfonylurea derivative chemically-[[p-[2-(3ethyl-4-methyl-2-oxo-3- pyyroline-1oxamide) ethyl] phenyl] sulfonyl]-3-(trans-4methylcyclohexyl) urea and also used in type

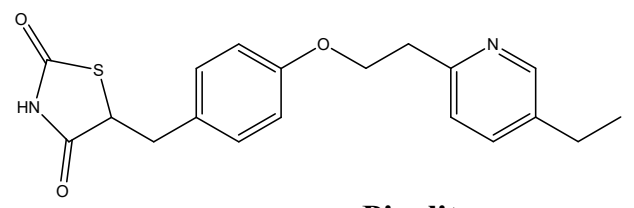

Figure 1: Structure of Pioglitazone

\section{MATERIALS AND METHODS}

\section{Chemicals and reagents}

Pioglitazone and Glimepride drugs were obtained as a gift from Arbindo Pharma Pvt Ltd. The reagents Methanol, Acetonitrile, Toluene, Ethyl acetate, Diethyl ether of Thermo scientific India.

\section{Instrumentation}

The HPTLC system manufactured by AETRON consists of Linomat - 5 sample applicator, variable wavelength programmable AETRON TLC Scanner - 3, AETRON Twin-trough chambers, Hamilton syringe $(100 \mu \mathrm{L})$. Chromatographic analysis was performed on aluminum packed silica
2 diabetes [3]. Glimepride binds to ATPsensitive potassium channel receptors. Reducing potassium conductance and causing depolarization of the membrane which stimulates calcium ion influx through voltage-sensitive calcium channels. This increase in intracellular calcium ion concentration induces the secretion of insulin [4].

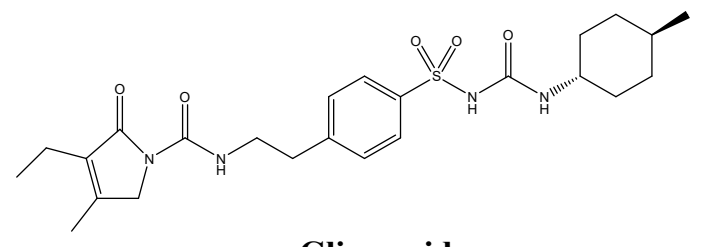

Glimepride

Figure 2: Structure of Glimepride

gel 60 F254 HPTLC plates (Merck, Darmstadt, Germany) using Spraylin software. Quantification is done through visible light, UV-254, 365nm with EOS utility using JUST TLC or AETRON IDS software.

\section{Mobile phase preparation}

For better resolution of Pioglitazone and Glimepride- Toluene: Ethyl acetate: Diethyl ether was used as mobile phase in the ratio of $6: 3: 1 \mathrm{v} / \mathrm{v} / \mathrm{v}$.

\section{Preparation of Standard stock solution}

Accurately weighed 150mg of Pioglitazone and $20 \mathrm{mg}$ of Glimepride in $100 \mathrm{ml}$ volumetric flask, $3 / 4^{\text {th }}$ diluent was added. The solution 
was sonicated for 30 minutes to dissolved and made up to volume with diluent. The solution were filtered through $0.45 \mu$ Millipore Nylon filter.

\section{Preparation of Sample solution}

Accurately weighed 20 tablets and average weight of the tablets was calculated.10 tablets were weighed and transferred into 100 ml volumetric flask with $70 \mathrm{ml}$ of diluent. The solution is sonicated for 30 minutes with intermediate shaking and made up to volume with diluent. Further solution is filtered through $0.45 \mu$ Millipore Nylon filter. Further, $6 \mathrm{ml}$ filtered solution is transferred into $10 \mathrm{ml}$ volumetric flask, diluted with diluents up to the volume.

\section{Optimization of HPTLC method}

The HPLTC method was optimized on $10 \mathrm{~cm} \times 10 \mathrm{~cm}$ aluminium TLC plate coated with silica gel $60 \mathrm{~F}$ 254. The plates were pre washed with methanol and activated at $60^{\circ} \mathrm{C}$ for $5 \mathrm{~min}$. The samples were spotted in form of bands with $8 \mathrm{~mm}$ width by using AETRON sample applicator equipped with $100 \mu \mathrm{L}$ Hamilton syringe. The application rate was $20 \mu \mathrm{L} / \mathrm{sec}$. Ascending mode of development on the plate was performed at $25 \pm 2^{0} \mathrm{c}$ using Toluene: Ethyl acetate: Diethyl ether $(6: 3: 1 \mathrm{v} / \mathrm{v})$ as mobile phase in a twin through glass chamber(AETRON, $10 \mathrm{~cm} \times 10 \mathrm{~cm})$ which is previously saturated with $10 \mathrm{ml}$ mobile phase for 30 minutes. The mobile phase was allowed to run up to $8 \mathrm{~cm}$. The plates were dried in air, after development. Documentation was performed at $365 \mathrm{~nm}$ with an AETRON TLC scanner equipped with Aetron IDS software, using a deuterium light source (Table 1).

\section{Method Validation}

The following parameters were validated according to ICH Q2 (R1) guidelines include linearity, precision, accuracy, robustness, limit of detection, limit of quantification.

\section{System suitability}

System suitability can be defined as a process of checking the system, before or during the analysis of unknowns, to ensure system performance. Accurately weighed $150 \mathrm{mg}$ of Pioglitazone and 20mg of Glimepride in $100 \mathrm{ml}$ volumetric flask $3 / 4^{\text {th }}$ diluent was added. The solution was sonicated for 30 minutes to dissolved and made up to volume with diluent. Further, $6 \mathrm{ml}$ filtered solution is transferred in to $10 \mathrm{ml}$ volumetric flask, diluted with diluents up to the volume. The solution was filtered through $0.45 \mu$ Millipore Nylon filter.30 $\mu \mathrm{L}$ of standard solutions of drug were injected in triplicate into chromatographic system. \%RSD was calculated for Pioglitazone and Glimepride (Table 2, Figure 3). 
Table 1: Optimized parameters for HPTLC method

\begin{tabular}{|c|c|}
\hline Stationary phase & $10 \mathrm{~cm} \times 10 \mathrm{~cm}$ silica gel 60 F 254 Aluminium sheets \\
\hline Mobile phase & Toluene: Ethyl acetate: Diethyl ether (6:3:1v/v) \\
\hline Dosage speed & $20 \mu \mathrm{L} / \mathrm{sec}$ \\
\hline Band length & $\mathbf{8 m m}$ \\
\hline Sample volume & $30 \mu \mathrm{L}$ \\
\hline Detection wavelength & $365 \mathrm{~nm}$ \\
\hline
\end{tabular}

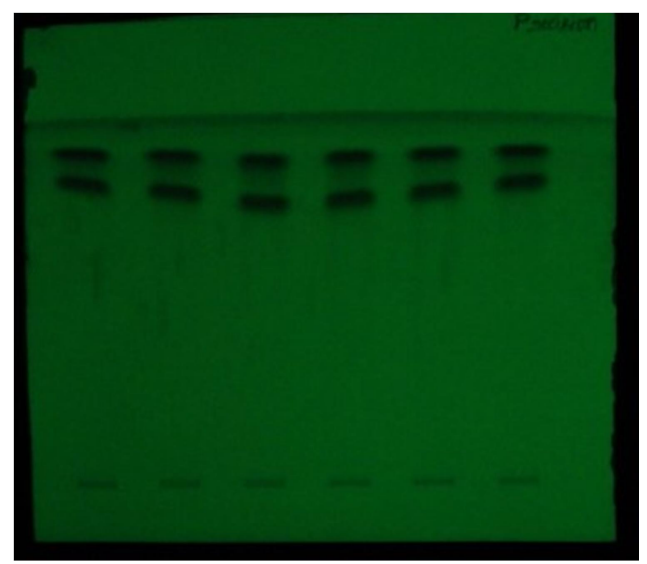

Figure 3: Chromatogram for system suitability

Table 2: System suitability data:

\begin{tabular}{|c|c|c|c|c|}
\hline \multirow{2}{*}{ S. No. } & \multicolumn{2}{|c|}{ Peak area } & \multicolumn{2}{c|}{ Rf values } \\
\cline { 2 - 5 } & PIO & GLI & PIO & GLI \\
\hline 1 & 1065 & 983 & 0.85 & 0.78 \\
\hline 2 & 1069 & 972 & 0.87 & 0.79 \\
\hline 3 & 1075 & 966 & 0.87 & 0.78 \\
\hline 4 & 1068 & 985 & 0.88 & 0.76 \\
\hline 5 & 1069 & 965 & 0.86 & 0.75 \\
\hline Mean & 1090 & 953 & - & - \\
\hline SD & 1072.667 & 972.33 & - & - \\
\hline \%RSD & 0.85 & 9.54 & - & - \\
\hline
\end{tabular}

Acceptance criteria: The \%RSD should be NMT $2.0 \%$

\section{Linearity}

Linearity of an analytical procedure is its ability to obtain test results which are directly proportional to the concentration of the analyte of the sample. The linearity was studied by using Toluene: Ethyl acetate: Diethyl ether $(6: 3: 1 \mathrm{v} / \mathrm{v})$ as mobile phase. Pipette out $4 \mathrm{ml}, 5 \mathrm{ml}, 6 \mathrm{ml}, 7 \mathrm{ml}, 8 \mathrm{ml}$ from standard stock solution and made up with diluents up to the volume. The development was carried out to obtain the calibration curves by plotting areas against corresponding concentrations (Table 3, Figure 4, 5).

\section{Accuracy}

The accuracy of the method was determined by performing recovery studies at 3 different concentrations $(50 \%, 100 \%, 150 \%$ levels $)$ by adding known amount of Pioglitazone and Glimepride. At each level 3 determinations 
were done. Percentage recovery were studied for both the drugs (Table 4, 5).

\section{Precision}

Precision refers to the closeness of two or more measurements to each other or it is the degree to which an instrument or process will repeat the same value (Table 6).

\section{LOD and LOQ:}

LOD and LOQ are the lowest concentration of the analyte which can be quantified and LOQ can be equivalent to or much higher than LOD. LOD and LOQ for Pioglitazone and Glimepride were calculated from linearity by using the formula (Table 7):

$$
\begin{aligned}
& \mathbf{L O D}=(3.3 \times \mathrm{SD} / \mathrm{S}) \\
& \mathbf{L O D}=(10 \times \mathrm{SD} / \mathrm{S})
\end{aligned}
$$

Where SD- standard deviation

S- Slope of the calibration curve

\section{Robustness}

\section{A: Chromatographic changes (Band length)}

The robustness of this method was studied by altering various parameters like change in dosage speed, change in band length etc.

\section{B: Chromatographic changes (Speed)}

The robustness of this method was studied by altering the dosing speed (20ng/sec and 16 ng/sec). (Table 8).

\section{ASSAY RESULTS}

20 tablets were weighed accurately and crushed into powder. From the pooled powder weighed equivalent to $150 \mathrm{mg}$ Pioglitazone and 20mg Glimepride into $100 \mathrm{ml}$ volumetric flask with diluent. From the above solution pipette out $6 \mathrm{ml}$ into $10 \mathrm{ml}$ volumetric flask and make up to the mark with diluents (Table 9).

\begin{tabular}{|c|c|c|c|c|}
\hline \multirow[t]{2}{*}{ SNO } & \multicolumn{2}{|c|}{ Pioglitazone } & \multicolumn{2}{|c|}{ Glimepride } \\
\hline & Con(ng/mL) & Area & Con(ng/mL) & Area \\
\hline 1 & 6000 & 721 & 800 & 642 \\
\hline 2 & 7500 & 912 & 1000 & 825 \\
\hline 3 & 9000 & 1078 & 1200 & 952 \\
\hline 4 & 10500 & 1264 & 1400 & 1123 \\
\hline 5 & 12000 & 1445 & 1600 & 1284 \\
\hline \multicolumn{2}{|c|}{ Regression equation } & $Y=1.023 x+0.833$ & \multicolumn{2}{|c|}{$Y=8.01 x+3.333$} \\
\hline \multicolumn{2}{|c|}{ Slope(m) } & 1.203 & \multicolumn{2}{|c|}{8.01} \\
\hline \multicolumn{2}{|c|}{ Correlation coefficient $\left(\mathbf{R}^{2}\right)$} & 0.9999 & \multicolumn{2}{|c|}{0.9999} \\
\hline
\end{tabular}

Table 3: Report of linearity

Acceptance criteria: The correlation coefficient (R2) should be NMT 0.999 


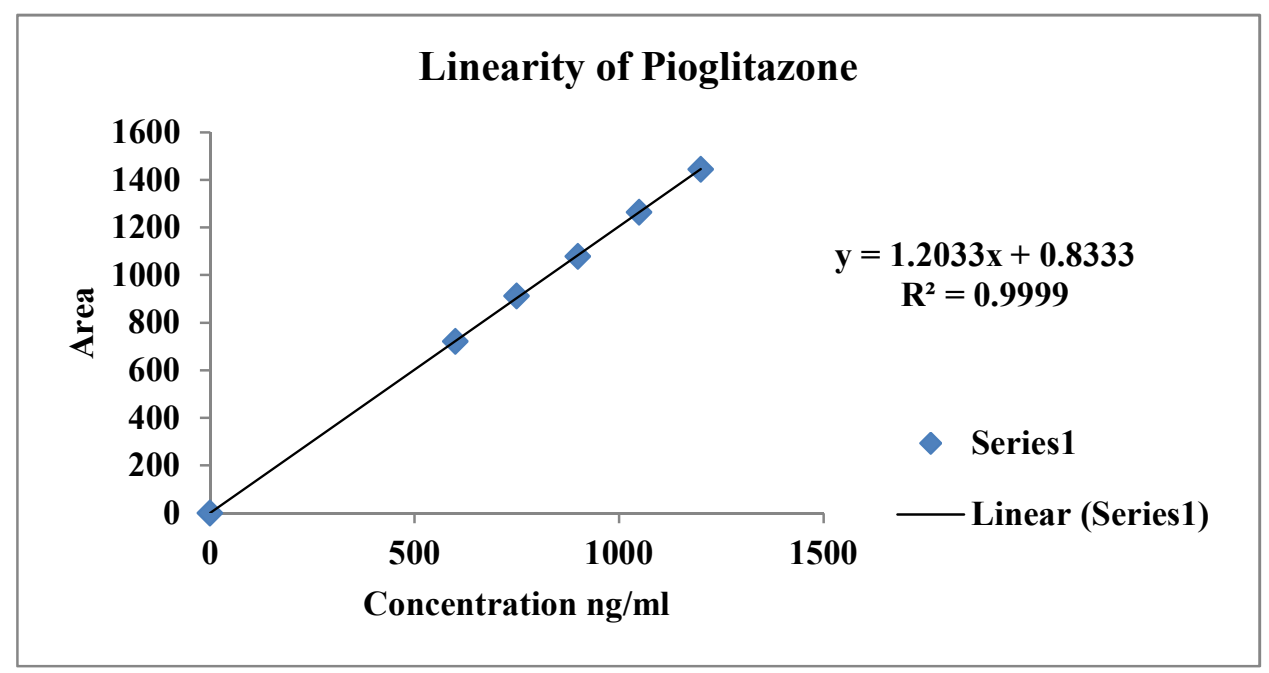

Figure 4: Calibration curve of Pioglitazone

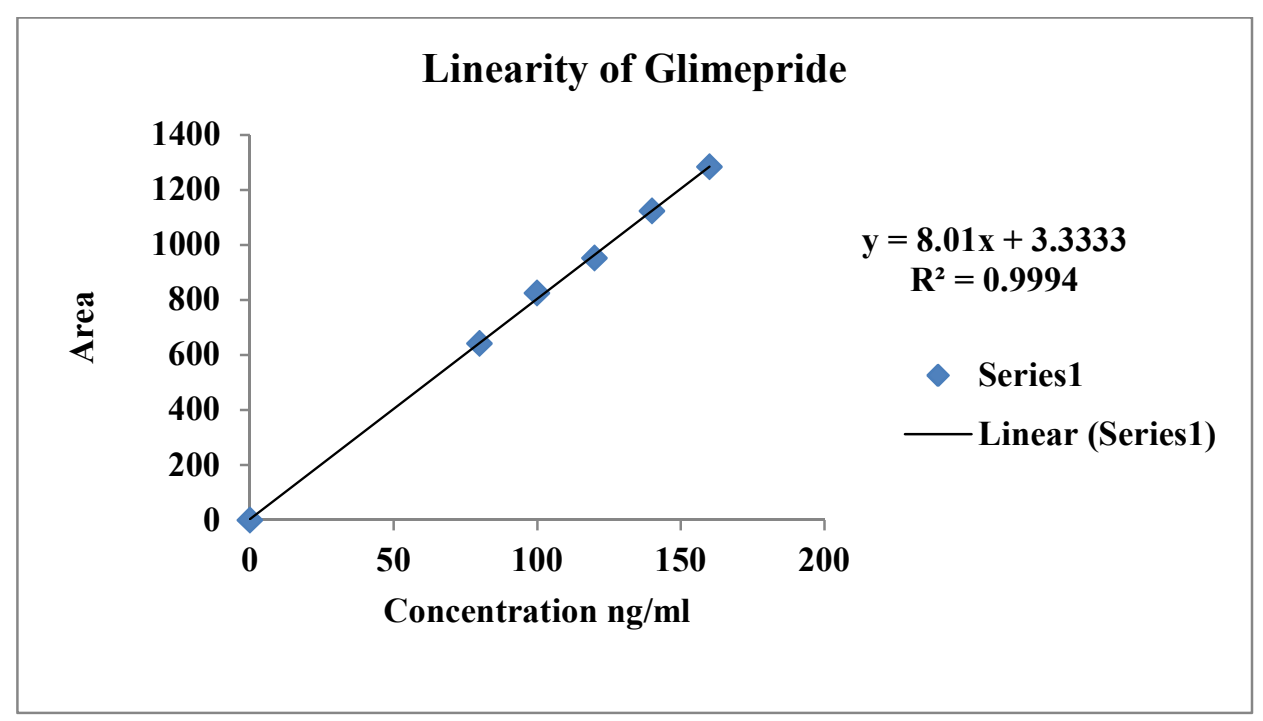

Figure 5: Calibration curve of Glimepride

Table 4: Accuracy data of Pioglitazone

\begin{tabular}{|c|c|c|c|c|c|}
\hline \multirow[t]{2}{*}{ Recovery level } & \multicolumn{4}{|c|}{ Accuracy of Pioglitazone } & \multirow{2}{*}{$\begin{array}{l}\text { Average } \\
\text { percentage } \\
\text { recovery }\end{array}$} \\
\hline & Standard area & Sample peak area & \% Recovery & \% Mean Recovery & \\
\hline \multirow[t]{3}{*}{50} & 1062 & 532 & 100.41 & \multirow[t]{3}{*}{100.066} & \multirow{9}{*}{100.06} \\
\hline & 1062 & 529 & 99.76 & & \\
\hline & 1062 & 531 & 100.03 & & \\
\hline \multirow[t]{3}{*}{100} & 1062 & 1065 & 100.57 & \multirow[t]{3}{*}{100.016} & \\
\hline & 1062 & 1058 & 99.82 & & \\
\hline & 1062 & 1056 & 99.66 & & \\
\hline \multirow[t]{3}{*}{150} & 1062 & 1594 & 100.33 & \multirow[t]{3}{*}{100.1} & \\
\hline & 1062 & 1589 & 100.03 & & \\
\hline & 1062 & 1587 & 99.94 & & \\
\hline
\end{tabular}


Table 5: Accuracy data of Glimepride

\begin{tabular}{|c|c|c|c|c|c|}
\hline \multirow{2}{*}{ Recovery level } & \multicolumn{4}{|c|}{ Accuracy of Glimepride } & \multirow{2}{*}{$\begin{array}{c}\text { Average } \\
\text { percentage } \\
\text { recovery }\end{array}$} \\
\hline & Standard area & Sample peak area & \% Recovery & $\begin{array}{l}\text { \% Mean } \\
\text { Recovery }\end{array}$ & \\
\hline \multirow[t]{3}{*}{50} & 955 & 472 & 99.06 & \multirow[t]{3}{*}{99.6} & \multirow{9}{*}{99.94} \\
\hline & 955 & 475 & 99.61 & & \\
\hline & 955 & 478 & $\mathbf{1 0 0 . 1 3}$ & & \\
\hline \multirow[t]{3}{*}{100} & 955 & 951 & 99.87 & \multirow[t]{3}{*}{99.99} & \\
\hline & 955 & 958 & 100.51 & & \\
\hline & 955 & 949 & 99.60 & & \\
\hline \multirow[t]{3}{*}{150} & 955 & 1435 & 100.44 & \multirow[t]{3}{*}{100.25} & \\
\hline & 955 & 1429 & 100.04 & & \\
\hline & 955 & 1432 & 100.28 & & \\
\hline
\end{tabular}

Acceptance criteria: The mean \% recovery for each level should not be less than $98.0 \%$ and NMT $102 \%$

Table 6: Precision data

\begin{tabular}{|c|c|c|c|c|}
\hline \multirow{2}{*}{ Injection No. } & \multicolumn{2}{|c|}{ Area of Pioglitazone } & \multicolumn{2}{c|}{ Area of Glimepride } \\
\cline { 2 - 5 } & Method precision & System precision & Method precision & System precision \\
\hline 1 & 1072 & 1062 & 973 & 953 \\
\hline 2 & 1063 & 1065 & 972 & 959 \\
\hline 3 & 1079 & 1069 & 987 & 966 \\
\hline 4 & 1052 & 1077 & 979 & 957 \\
\hline 5 & 1063 & 1068 & 985 & 968 \\
\hline Mean & 1021 & 1095 & 979 & 960 \\
\hline SD & 1058.333 & 1072.667 & 999.1667 & $\mathbf{9 6 7}$ \\
\hline \%RSD & 12.04 & 5.79 & 1.93 & 0.08 \\
\hline
\end{tabular}

Acceptance criteria: The \%RSD should be NMT $2.0 \%$

Table 7: LOD and LOQ for Pioglitazone and Glimepride

\begin{tabular}{|c|c|c|}
\hline SNO & PIO & GLI \\
\hline LOD $(\mu \mathrm{g} / \mathrm{ml})$ & 2.75 & 1.10 \\
\hline LOQ $(\mu \mathrm{g} / \mathrm{ml})$ & 8.34 & 3.33 \\
\hline
\end{tabular}

Table 8: Report of Robustness data

\begin{tabular}{|c|c|c|}
\hline Parameter & Area of Pioglitazone & Area of Glimepride \\
\hline Change in Band length & 1121 & 970 \\
9mm & 1107 & 965 \\
\cline { 2 - 3 } Change in Band length & 1098 & 960 \\
\cline { 2 - 3 } 7mm & 1096 & 952 \\
\hline Average & 1105.5 & 961.75 \\
\hline Standard deviation & 11.38 & $\mathbf{0 . 7 9 8}$ \\
\hline ChSD & 1.0300 & 975 \\
\hline Change in Dosage speed & 1073 & 979 \\
\cline { 2 - 3 } 16mL/sec & 1082 & 987 \\
\hline 20mL/sec & 1092 & 988 \\
\hline Average & 1095 & 982.25 \\
\hline Standard deviation & 1085.5 & 6.29 \\
\hline \%RSD & 10.01 & 0.640 \\
\hline
\end{tabular}

Acceptance criteria: The \%RSD should be NMT $2.0 \%$

Table 9: Results of Assay

\begin{tabular}{|c|c|c|}
\hline Drug & Label claim & \% Assay \\
\hline Pioglitazone & 150 & 99.48 \\
\hline Glimepride & 20 & 99.82 \\
\hline
\end{tabular}




\section{CONCLUSION}

Simple, specific and accurate method was developed for simultaneous determination of Pioglitazone and Glimepride by HPTLC method and validated according to ICH Q2 (R1) guideline in terms of linearity, precision, accuracy, robustness, limit of detection, limit of quantification. The linearity was in the range of 6000-12000 $\mathrm{ng} / \mathrm{ml}$ for Pioglitazone and 800-1600 ng/ml for Glimepride. The best regression values were obtained. The recovery studies were performed for the accuracy of the proposed method and was found to be $100.06 \%$ for Pioglitazone and 99.94\% for Glimepride. The LOD and LOQ for Pioglitazone was $2.75 \mu \mathrm{g} / \mathrm{ml}, 8.34 \mu \mathrm{g} / \mathrm{ml}$ and for Glimepride it was found to be $1.10 \mu \mathrm{g} / \mathrm{ml}$ and 3.33 $\mu \mathrm{g} / \mathrm{ml}$. The Rf values for Pioglitazone and Glimepride were found to be 0.88 and 0.79 . Hence the developed method was successfully applied for the estimation of Pioglitazone and Glimepride by HPTLC method.

\section{ACKNOWLEDGEMENT}

I am very grateful to Chalapathi Institute of Pharmaceutical Sciences, Lam, Guntur, for Providing support, guidance and necessities.

\section{REFERENCES}

[1] Dhirender Singh, S.C., Dwivedi, Ashok Kushnoor. "Development and validation of a

HPTLC method for simultaneous estimation of pioglitazone and in bulk and tablet dosage form", International Journal of Biomedical and Advance Research. 4(11): Pp. 3919-3921.

[2] Sakamoto, J., Kimura, H., Moriyama, S., Odaka, H., Momose, Y., Sugiyama, Y., (2000). "Activation of human peroxisome proliferator- activated receptor (PPAR) subtypes by Pioglitazone," Biochem Biophys Res, 278(3): Pp704-11.

[3] Kalyankar, T.M., Badgujar, M.R., Mitkare, S.S., Kakde. R.B., (2010). "HPTLC Method for simultaneous Analysis of [Pioglitazone $\mathrm{Hcl}$ and Glimipride in Pharmaceutical Preparations", J Pharm Res. 3(12).

[4] Kiran, Shinde, K., Nachiket, Dighe, S., (2020). "A review on voglibose, glimipride, metformin hydrochloride in bulk and tablet dosage form". International Journal of Research in Engineering, Technology and Science, 13 (8).

[5] Parthiban, C., Bhagavanraju, M., Sudhakar, M., Siddartha, B., (2013). "Simultaneous determination and validation of pioglitazone and 
glimepiride in tablet dosage form by

HPTLC method", International Journal of Pharmacy and Pharmaceutical Sciences. 5(4): Pp619-622.

[6] Dhirender singh, Dwivedi, S.C., Ashok Kushnoor. "Development and validation of a HPTLC method for simultaneous estimation of pioglitazone and glimipride in bulk and tablet dosage form", International Journal of Biomedical and Advance Research. 2. (9): Pp. 368-377.

[7] Meeta, Jiladia, A., Pandya, S.S., Viidyasagar G., (2009). “A simple and sensitive HPTLC method for estimation of pioglitazone in bulk and tablet dosage forms", Asian J Research Chem. 2(2).

[8] Abdel Mohammad, Fardous Mohamed, (2013). "New and Selective HPTLC- Densitometric Method for determination of Pioglitazone Hcl", Journal of Planar Chromatography- Modern TLC. 26 (3).

[9] Seema, Dhole M., Pramod, Khedekar, B., Nikil, Amnerkar, D., (2013) “ Development and validation of HPTLC method for simultaneous estimation of Rosiglitazone and Glimipride in fixed tablet dosage form". Journal of the Chilean chemistry society. 58. (2).

[10] Kalaiselvi, P., Amirtharaj, R., Vijay, Venkatachalam, T., Kumar, Senthil, N., (2010), “HPTLC method for simultaneous determination of pioglitazone $\mathrm{HCl}$ and Telmisartan in tablet dosage form", Asian Journal of Researchin Chemistry. 3(1): Pp 60-62.

[11] Miral Rank, Pankaj Kapupara, Ketan Shah, (2016), "Development and validation of stability indicating HPTLC method for Pioglitazone Hydrochloride and Metformin Hydrochloride”, Research Journal of Pharm and Tech, 9(10): Pp1555-1561.

[12] Komal Sharma, Amritha Parle, (2015), "Development and validation of HPTLC Method for simultaneous estimation of Alogliptin Benzoate and Pioglitazone Hydrochloride in Bulk Drugs and Combined Dosage Forms", International Journal of 
Pharma Research and Review. 4 (11): Pp35-42.

[13] Sunil, Dhaneswar, R., Janaki, Salunkhe,V., Vidya Kishore Bhusari, (2010), "Validated HPTLC Method for simultaneous estimation of Metformin Hydrochloride, Atorvastatin and Glimepride in Bulk Drug and Formulation",1(3).

[14] Dipak Kale, Rajendra, Kakde.B., (2011), "Simultaneous Determination of Pioglitazone, Metformin, Glimipride in pharmaceutical preparations using HPTLC Method. Journal of Planar Chromatography- Modern TLC", 24(4): Pp331-336.

[15] Rajesh Varade, Harsha Mishra, (2019), “A Rapid uniDimensional Development HPTLC -Densitometry Method For Simultaneous Estimation of Metformin Htdrochloride, Gliclazide and Pioglitazone Hydrochloride", International Journal Of Pharmacy and Pharmaceutical Sciences. 11(7). 